Dino HAJDAR

Fakultet humanističkih nauka Univerziteta „Džemal Bijedić“ Mostar

E-mail: dino.hdr26@gmail.com

Stručni rad/Professional article

UDK/UDC: 94:32:929Mikulić(497.6)"1965/1989"

Sarač-Rujanac Dž. (049.3)

DOI: https://doi.org/10.52259/historijskipogledi.2021.4.5.307

\title{
Dženita Sarač-Rujanac, BRANKO MIKULIĆ: POLITIČKA BIOGRAFIJA 1965-1989, Institut za historiju Univerziteta u Sarajevu, Sarajevo 2020, 557 str.
}

Naučno pisati političku biografiju, riječima načiniti objektivan portret ličnosti u datom vremenskom okviru, zasigurno predstavlja težak i izazovan posao. Tim više što je moderna historiografija sklonija analiziranju historijskih

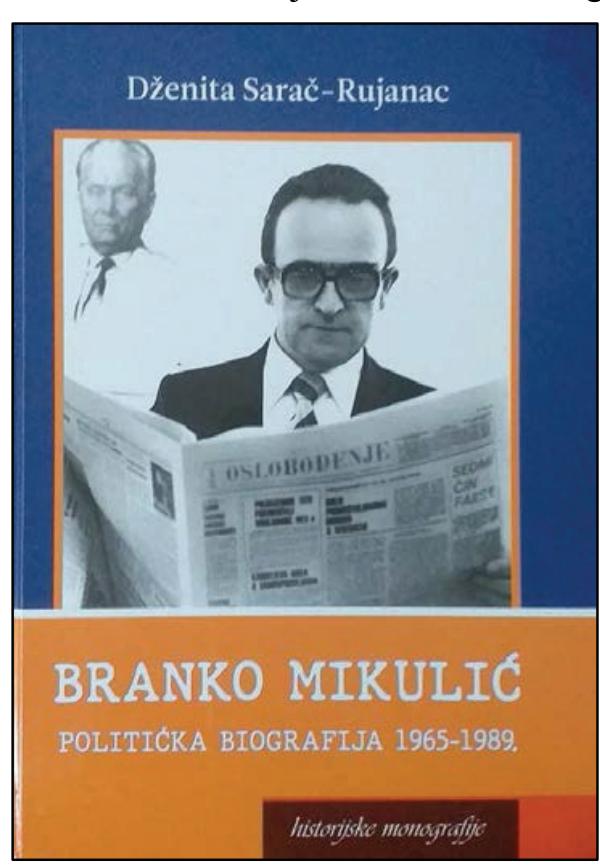
procesa, čiji se akteri, često, nalaze van fokusa istraživanja. Ipak, studije koje posmatraju određenu ličnost u kontekstu vremena njenog djelovanja proširuju saznanja o prošlosti, pogotovo ako se radi o političkim akterima koji su bili duboko involvirani u društvene procese. Takva ličnost je, nesumnjivo, Branko Mikulić, istaknuti dugogodišnji član rukovodstva Saveza komunista i državnih institucija Bosne i Hercegovine i Jugoslavije, te jedan od reprezenata socijalističke prošlosti naše zemlje. Njegova politička djelatnost od 1965 . do 1989. godine tema je knjige dr. sc. Dženite Sarač-Rujanac, naučne saradnice na Institutu za historiju u Sarajevu, pod naslovom Branko Mikulić: Politička biografija 1965-1989. Knjiga je iz štampe izašla 2020. godine u izdanju Instituta za historiju u Sarajevu i plod je dugogodišnjeg autoričinog zanimanja i istraživanja političke djelatnosti Branka Mikulića, što je bila i tema njene doktorske disertacije odbranjene na Filozofskom fakultetu u Sarajevu 2016. godine. 
Nakon Uvoda (9-41), u kojem autorica upoznaje čitateljstvo zbog čega se odlučila za poduhvat pisanja ove studije, precizira konceptualna i teorijska polazišta prilikom pisanja iste, te se osvrće na rani životni put Branka Mikulića, priču o njegovoj biografiji u naslovom određenom periodu započinje prvim tematskim dijelom knjige pod nazivom Prvi koraci u republičkom rukovodstvu. Branko Mikulić između Cetvrtog (1965) i Petog (1969) Kongresa SK Bosne i Hercegovine (47-69). Prekratnica u političkoj karijeri Branka Mikulića, ističe autorica, bilo je imenovanje za sekretara CK SKBiH 1965. godine, postavši tako dio ambicioznog rukovodstva koje je pokrenulo novu etapu svestranog razvoja Bosne i Hercegovine. Kao sekretar CK i ekonomista po struci Mikulić je bio aktivno uključen u diskusiju o privrednoj reformi, koja je usvojena 1965. godine, te je bio angažiran u radnoj grupi za ocjenu aktivnosti sprovođenja iste. Sarač-Rujanac smatra da je njegovo unaprijeđenje na funkciju sekretara Izvršnog vijeća Skupštine SR Bosne i Hercegovine 1967. godine značilo snažnije involviranje u ključne procese koje je pokrenula rukovodeća politička elita, sa ciljem društvenog i privrednog razvoja Republike i jačanja njenog položaja u Federaciji.

Na čelu Saveza komunista Bosne i Hercegovine (69-85) naslov je narednog dijela knjige, u kojem je prikazan kontekst izbora i djelovanja Branka Mikulića na funkciji predsjednika CK SKBiH. Potkraj šezdesetih godina prošlog stoljeća, kada je otvorena reforma Federacije, narušli su se odnosi između pojedinih republika, što se refektiralo na rasprave o popunjavanju saveznih institucija. Posebna pažnja bila je usmjerena na imenovanje Saveznog izvršnog vijeća (SIV). Sarač-Rujanac piše da se tokom razgovora o novom sastavu SIV-a 1968. godine spominjalo ime Branka Mikulića kao člana Savezne vlade čiji je mandatar trebao biti Stane Kavčić. Ipak, nakon što je za mandatara imenovan drugi Slovenac, Mitija Ribičić, pitanje Mikulićevog imenovanja u SIV odloženo je na određeno vrijeme. Na Petom kongresu SKBiH u januaru 1969. godine on je izabran za predsjednika CK SKBiH. O njegovom pozitivnom angažmanu na ovoj poziciji, autorica navodi riječi Josipa Broza Tita sa sjednice Izvršnog biroa SKJ 1971. godine, kada se ponovo aktuliziralo pitanje Mikulićevog imenovanja u SIV, ovog puta kao mandatara, koji je ocijenio situaciju u Bosni i Hercegovini poprilično dobrom, možda i najboljom u Jugoslaviji i insistirao na tome da Mikulić ostane u Republici. Na Šestom kongresu SKBiH 1974. godine, Mikulić je ponovo izabran za predsjednika njegovog CK i na tom položaju je ostao do 1978. godine kada biva imenovan u Predsjedništvo CK SKJ.

Naredne četiri godine Mikulić je obnašao funkciju člana Predsjedništva savezne Partije, a njegovu djelatnost na toj funkciji tematizira treći dio knjige pod naslovom Branko Mikulić u Predsjedništvu CK SKJ (1978-1982) (85-105). Autorica ističe da je Mikulićev odlazak u vrh SKJ tada podržao i Josip Broz Tito, koji je insistirao da upravo on bude imenovan za prvog predsjedavajućeg novog saziva Predsjedništva CK SKJ. Razmatrajući obilježja njegovog jednogodišnjeg mandata kao predsjedavajućeg, Sarač-Rujanac izdvaja njegov angažman po pitanju kolektivnog rada i primjene jednogodišnjeg mandata te 
intenziviranja markističkog obrazovanja, kao i blisku saradnju sa Josipom Brozom Titom, koja je od samog početka 1970-ih godina bila vrlo intenzivna. U pogledu na rješavanje ekonomske krize, koja je početkom osamdesetih godina uzdrmala Jugoslaviju, autorica zaključuje da se Mikulić u Predsjedništvu CK SKJ bavio problemima ekonomske krize, ali da se njegova uloga može svesti na upozoravanje i obznanjivanje krize kao i na insistiranju na snažnijoj partijskoj uključenosti u provedbu ekonomske stabilizacije. Tek se njegovim imenovanjem za predsjednika SIV-a 1986. godine može govoriti o konkretnom, ličnom zalaganju u nastojanju da se izvrše značajne promjene i da se kriza prevaziđe.

O ponovnom angažmanu Branka Mikulića u Bosni i Hercegovini, ovaj put u republičkom Predsjedništvu, govori novi dio knjige Branko Mikulić $u$ Predsjedništvu SRBiH 1982-1984 (105-131). Nakon što je u aprilu 1982. godine Skupština SRBiH usvojila prijedlog da se imenuje za predsjednika Predsjedništva SRBiH, Branko Mikulić je postao prvi čovjek Republike. SaračRujanac upozorava da je aktivnost Branka Mikulića u republičkom Predsjedništvu bila pod snažnim uticajem jugoslovenske ekonomske krize, koja se osjećala i u Bosni i Hercegovini. On je kao predsjednik i član ovog tijela bio uključen $u$ akutelne diskusije o političkim i ekonomskim problemima, te se zalagao za snažne zaokrete u privredi kao što su usmjerenje ka domaćim resursima, povećanje produktivnosti rada, zapošljavanje mladih i slično. Posebnu pažnju autorica posvećuje njegovim aktivnostima kao predsjednika Organizacionog komiteta XIV zimskih olimijskih igara u Sarajevu. Zimske olimijske igre koje su održane u februaru 1984. godine u javnosti su ocijenjene kao najbolje organizirane u dotadašnjoj historiji olimpijskog pokreta, što je, zaključuje Sarač-Rujanac, Mikuliću donijelo epitet vještog i posvećenog menadžera, što će mu značajno pomoći u daljem razvoju političke karijere.

U petom dijelu knjige Ponovo u saveznom centru 1984-1989 (131-211) autorica razmatra političku djelatnost Branka Mikulića u svojstvu člana Predsjedništva SFRJ i mandatara SIV-a. Imenovanje u savezno Predsjedništvo 1984. godine, smatra autorica, bio je vrlo značajan korak u političkoj karijeri Branka Mikulića. Novo predsjedništvo se suočilo sa dugogodišnjim problemima ekonomske i sve evidentnije političke krize. Ono što je posebno otežavalo rad Predsjedništva bila je njegova ukliještenost između SIV-a i SKJ, kao dva centra moći čije su se percepcije daljeg razvoja jugoslovenskog društva značajno razlikovale. U tom periodu Mikulić postaje gorljivi zagovornik jačanja državnih, jugoslovenskih interesa, državnih institucija, snažnije saradnje rukovodećih institucija, te jačanja partijskog jedinstva i njene aktivnosti. Izborne 1986. godine Branko Mikulić je, kao kandidat Predsjedništva, dobio mandat predsjednika SIV-a. Analizirajući inicijative, mjere, programe i politiku novog saziva SIV-a, autorica ukazuje da se Mikulić, kao njegov predsjednik, angažirao na rješavanju brojnih problema privrednog razvoja, oko kojih su i do tada vođene oštre rasprave koje su bile i rezultat, ali i povod daljih međurepubličkih neslaganja, te da je politika koju je vodio kao savezni premijer polazila od 
osnovnih postavki „Antiinflacionog programa“. Različiti republički pogledi na prevazilaženje krize i privrednu reformu komplicirali su rad SIV-a. Ovaj problem autorica analizira kroz prizmu otvorenog protivljenja SR Slovenije i SR Hrvatske politici Mikulićeve vlade, kao i kroz primjere kritike jugoslavenske štampe, koja je bila motivirana pluralizmom interesa u Jugoslaviji i svakodnevnom jačanju frontovske pozicije, na jednoj strani pojedinih republika, a na drugoj Federacije. Nakon neuspješnih napora SIV-a, sa ciljem prevazilaženja krize, uslijedila je kolektivna ostavka ovog tijela na zasjedanju Saveznog vijeća Skupštine SFRJ 28. decembra 1988. godine. U pogledu na prvu ostavku jedne vlade u historiji socijalističke Jugoslavije, Sarač-Rujanac ukazuje da ovaj presedan, koji se u literaturi često pretenciozno naglašava, ipak nije kuriozitet Mikulićeve vlade. Svoja razmišljanja argumentira činjenicom da je i prethodna predsjednica SIV-a, Milka Planinc, u dva navrata nudila svoju ostavku.

Nakon razmatranja hronološkog toka političke karijere Branka Mikulića, posljednji tematski i sadržajno najobimniji dio knjige Ključna pitanja političkog djelovanja Branka Mikulića (211-483) tretira glavne pravce njegovog djelovanja kao istaknutog kadra Partije i državnih institucija na republičkom i saveznom nivou. Razmatrajući njegovu ulogu u razvoju Bosne i Hercegovine, autorica navodi primjere snažnog političkog angažmana Branka Mikulića u privrednom jačanju ove republike tokom 1970-ih godina i afirmaciji bosanskohercegovačkog društva na obrazovnom i kulturnom planu, koji je smatrao da politički i ekonomski razvoj mora pratiti adekvatan razvoj kulture i umjetnosti. U isto vrijeme dok je rukovodstvo u Bosni i Hercegovini djelovalo u pravcu razvoja Republike, na saveznom nivou su vođene „bitke“ za jačanje njenog položaja u Federaciji. Borbu za ravnopravan položaj Republike u Federaciji autorica posmatra u kontekstu diskusija o dopunskim sredstvima Federacije u drugoj polovini 1960-ih godina, pitanju obnove Bosanske Krajine nakon razornog zemljotresa i rasprava o ustavnoj reformi Federacije u koje je Mikulić bio duboko involviran. Dovršavanje državnosti Bosne i Hercegovine i njene ravnopravnosti u SFRJ donijela je reforma federacije, kojom su republike ostvarile suverenitet. Mikulić je smatrao da je reforma iz 1971. godine konačno trebala omogućiti proklamirani i usvojeni dogovor na Drugom zasjedanju AVNOJ-a o ravnopravnosti Bosne i Hercegovine i ravnopravnosti u njoj. U ovom obimnom i iscrpnom dijelu knjige Sarač-Rujanac posmatra i političku djelatnost Branka Mikulića u uslovima narušenih međurepubličkih odnosa u Federaciji, posebno u periodu Hrvatskog proljeća početkom 1970-ih godina. Iako je na početku razgovora i diskusija o Hrvatskom proljeću zajedno sa bh rukovodstvom podržao nastojanja rukovodstva SK Hrvatske da se uspostavi politika čistih računa, Mikulić se posebno angažirao da ideje Hrvatskog proljeća, koje je poticala Matica Hrvatska, ne ostvare značajan uticaj na stanovništvo u Bosni i Hercegovini. Ipak, bh rukovodstvo vremenom je bivalo sve više bliže stavu da se trenutno hrvatsko rukovodstvo treba smijeniti. Nakon što je na 21. sjednici Predsjedništva SKJ hrvatsko vodstvo „ukoreno“ zbog 
popuštanja nacionalizmu, Mikulić se posvetio tumačenju zaključaka ove sjednice, insistirajući na njihovoj realizaciji, te ukazivanju šta sve može da donese eskalacija, kako hrvatskog, tako i srpskog i muslimanskog nacionalizma. Inače su borba sa nacionalizmom, kao klasnim neprijateljem radničke klase, i nacionalno pitanje, veoma osjetljivo u višenacionalnim zajednicama, kakve su bile i SFRJ i Bosne i Hercegovina, značajno su obilježili političku djelatnost Branka Mikulića. U tom smislu, autorica analizira stalni Mikulićev napor u suzbijanju nacionalističkih pojava u Bosni i Hercegovini, kako onih koje su nastajale u Republici, tako i onih koje su dolazile iz susjedstva i emigracije, kao i njegov doprinos u afirmaciji i priznavanju bošnjačke nacije, tada pod imenom Muslimani, prepoznavajući ga kao jednog od inicijatora višegodišnje diskusije o „muslimanskom identitetu“. O političkim izazovima predsjednika SIV-a 1980-ih godina Sarač-Rujanac piše da se on kao predsjednik Savezne vlade našao u središtu političke borbe između struje koja je insistirala na promjenama $u$ privrednom sistemu i snaga koncentriranih u partijskom rukovodstvu koje su grčevito nastojale zadržati postojeće stanje. I sam Mikulić je, kao predsjednik Savezne vlade, često kritikovao nejedinstvo unutar SKJ i uticaj republičkih interesa na Partiju, koja je za vrijeme njegovog mandata i dalje bila ključni centar moći. U atmosferi sve izrazitije krize u Jugoslaviji, krajem 1980-ih godina bh rukovodstvo sistematski je destabilizirano nizom medijski popraćenih afera, od kojih su afere „Agrokomerc“ i „Neum“ imale najviše odjeka. Smjenjivanjem i političkim marginaliziranjem Hamdije Pozderca i Milanka Renovice, srušeno je snažno dugogodišnje rukovodstvo ove republike. Autorica postavlja pitanje da li je i Mikulić bio meta političke diskreditacije ovim aferama i zaključuje da nije bilo argumenata za postavljanje pitanja njegove lične odgovornosti. Ipak, cjelokupna dešavanja izazvana aferama, kao i imenovanje novog rukovodstva uslovili su da Mikulić ostane bez političke podrške u matičnoj republici, nakon čega je podnio ostavku na mjesto predsjednika SIV-a. Poslije toga on se našao u potpunoj političkoj izolaziciji u uslovima uvođenja političkog pluralizma u Bosni i Hercegovini, a u ratnim uslovima iz opkoljenog Sarajeva intenzivno je slao apele na adrese brojnih svjetskih istaknutih političara za pomoć Bosni i Hercegovini, zaustavljanju ratnih dejstava i očuvanja njenog suvereniteta i teritorijalne cjelovitosti.

Obimna i naučno utemeljena studija dr. sc. Dženite Sarač-Rujanac o političkoj djelatnosti Branka Mikulića sinteza je, zaista plodne, političke karijere istaknute ličnosti socijalističke prošlosti Bosne i Hercegovine. U knjizi je autorica detaljno analizirala ključne pravce Mikulićevog djelovanja, nikako ne zanemarujući cjelokupnu atmosferu u Jugoslaviji i Bosni i Hercegovini u tom periodu. To potvrđuje i širok spisak objavljenih i neobjavljenih izvora, štampe i literature kojom se autorica analitički koristila prilikom pisanja ove studije, kao i veoma utemeljeni zaključci izvedeni na osnovu njih. Takvim pristupom autorica je objektivno rekonstruirala političku biografiju Branka Mikulića. Pored bogatog i jasnog tekstualnog sadržaja, knjiga je upotpunjena ilustracijama i sa tri seta zabilježenih fotografija Branka Mikulića tokom njegove političke karijere. 
Uzevši u obzir sve navedeno, smatramo da je Sarač-Rujanac ovom studijom lik i djelo Branka Mikulića smjestila u mozaik bosanskohercegovačke i jugoslovenske historije XX vijeka, te da je bosanskohercegovačka historiografija bogatija za još jednu, veoma vrijednu, političku biografiju značajne historijske ličnosti. 